\title{
Recession or Depression?
}

\author{
Kevin L. Kliesen, Economist
}

$\mathrm{O}$ n December 1, 2008, the Business Cycle Dating Committee of the National Bureau of Economic Research (NBER) determined that a peak in U.S. economic activity occurred sometime in December 2007. Although we have few insights about the eventual duration and depth of the current recession, many prominent economists, policymakers, and business leaders have asserted that the current recession will be the worst since the Great Depression. While parallels with the 1930s appear misplaced, it is certainly possible that the current recession might be as severe as any experienced since then.

\section{"Although the current recession may... be the longest in the postwar period, it is by no means certain that it will be the deepest, but it's increasingly looking that way."}

The U.S. recessions of 1973-75 and 1981-82 are generally seen as the most severe in terms of both their depth and their duration. However, those recessions were still mild compared with the 20th century's worst economic calamity - the Great Depression of 1929-33. To properly determine whether the current recession is comparable to any of these previous episodes requires some judgment not only about the actual and expected depth and duration of the current recession, but also about what variables are used to measure depth and duration. ${ }^{1}$

\section{Duration}

It is normal for the U.S. economy to grow-that is, to see increases in measures of economic activity such as real incomes and expenditures. During the post-World War II period, the average business expansion has lasted 57 months. Recessions, while not uncommon, are relatively short-with an average duration of 10 months. It appears, however, that the cur- rent recession will be considerably longer than that: As noted, the NBER determined that the most recent business cycle peak occurred in December 2007, which was about 16 months ago at the time of this writing. Moreover, the latest consensus forecast from the Federal Reserve Bank of Philadelphia's Survey of Professional Forecasters (SPF) predicts negative growth in real GDP through the second quarter of 2009; most Federal Reserve governors and presidents believe that a return to positive growth is likely in 2009, but not until the third or fourth quarters. $^{2}$

If a trough does occur sometime during the third or fourth quarters of 2009, then the 2007-09 recession will have been between 20 and 25 months in duration. In that case, the current recession will indeed have been the longest since the 43month contraction experienced from August 1929 to March 1933. The next-longest recessions in the postwar period were 16 months, for both the 1973-75 and 1981-82 recessions. Although the current recession may indeed turn out to be the longest in the postwar period, it is by no means certain that it will be the deepest, but it's increasingly looking that way.

\section{Depth}

The most conventional method of measuring a recession's depth is to calculate the percentage change in real GDP or the percentage-point change in the unemployment rate from the peak to the trough. The table shows the average values
Measures of Recession Depth and Duration

\section{Depth}

Duration (months) Real GDP

\begin{tabular}{lcccc}
\hline Average, 1948-2001 & 10 & -2.05 & -2.20 & 2.85 \\
Current episode & 16 & -1.73 & -0.36 & 3.67 \\
Current + SPF forecast & $20-22$ & -2.83 & NA & 4.60 \\
Great Depression & 43 & -26.50 & -26.70 & 24.60
\end{tabular}

NOTE: Depth measures the average percent change from peak to trough for real GDP and real $\mathrm{GDI}$ and the average percentage-point change from trough to peak for the unemployment rate. Changes in real GDP and real GDI during the Great Depression are based on annual data.

SOURCE: Author's calculations based on quarterly data. 
for all recessions since the 1948-49 recession. It also shows the equivalent income-side measure of real GDP, real gross domestic income (GDI), because the NBER notes that this value was important in establishing this recession's December 2007 peak. $^{3}$ (Note: In the table, the peak-to-trough changes in real GDP and the unemployment rate are based on actual peaks and troughs for each particular recession episode, rather than the official NBER-determined peak and trough quarters. Although the peak and trough quarters for real GDP line up closely with the NBER dates, the actual peak and trough dates for the unemployment rates can be considerably different from the NBER dates. ${ }^{4}$ )

During the post-World War II recessions, the mean decline in real GDP is 2.1 percent, the mean decline in real GDI is 2.2 percent, and the unemployment rate rises by an average of 2.9 percentage points. ${ }^{5}$ The second line of the table provides comparable measures for the current episode. Although the NBER dated the business cycle peak in the fourth quarter of 2007 (December), the actual peak in real GDP did not occur until the second quarter of 2008. While significant, the 1.75 percentage-point drop in real GDP through the fourth quarter of 2008 for the current recession is modestly less than its postwar average. Real GDI peaked in the third quarter of 2007 , but the decline since then has been fairly modest (a little more than one-third of a percentage point). By contrast, the unemployment rate reached its trough of 4.4 percent in the fourth quarter of 2006, and it has subsequently risen to 8.1 percent in February 2009. This increase, 3.7 percentage points, is nearly 1 percentage point larger than the normal increase in the unemployment rate seen during postwar recessions ( 2.85 percentage points). For purposes of comparison, the unemployment rate rose from 7.4 percent to 10.7 percent during the 1981-82 recession and from 4.8 percent to 8.9 percent during the 1973-75 recession. Thus, parallels between the current recession and the 1930s appear to be driven more by labor market conditions than actual declines in output. Of course, the other side of this story, which does not receive much attention, is that labor productivity growth continues to be relatively strong during this recession. ${ }^{6}$

The third line of the table shows the peak-to-trough changes based on quarterly SPF forecasts published in February 2009. (Forecasters are not asked to forecast the growth of real GDI.) The SPF projects that the trough of real GDP will occur in the second quarter of 2009, with a projected peak-to-trough decline of 2.8 percent. This decline would be modestly larger than the average of all episodes ( -2.1 percent). Given that the growth of real GDP during the fourth quarter of 2008 was revised from -3.8 percent in the advance estimate to -6.2 per- cent in the preliminary estimate, it seems possible that SPF forecasters might now forecast a deeper and longer recession. ${ }^{7}$ Indeed, if forecasters are correct that real GDP will decline at about a 5 percent annual rate in the first quarter of 2009, then the cumulative rate of decline in real GDP over the six months ending in March 2009 would be the second- or third-largest two-quarter rate of decline in the postwar period.

The SPF also forecasts that the unemployment rate will rise to an average of 9 percent in the first quarter of 2010. This level would produce a peak-to-trough increase in the unemployment rate during the current recession of 4.6 percentage points. ${ }^{8}$ In contrast to real GDP or real GDI, this rise in the unemployment rate would be the largest of all the postwar recessions. However, it would still fall far short of the 1929-33 episode, when the unemployment rate rose from 0.8 percent in July 1929 to 25.4 percent in March 1933 (an increase of 24.6 percentage points). ${ }^{9}$

It seems highly likely that the current recession will be the longest in the postwar period, at slightly less than two years according to the consensus of professional forecasters. Moreover, the 2007-09 recession may even be deeper than the average of all postwar recessions. However, parallels with the downturn of the 1930s are sorely misplaced-at least as measured by the actual and expected decline in real GDP, real GDI, or the rise in the unemployment rate.

Hall, Robert E. "How Much Do We Understand about the Modern Recession?" Brookings Papers on Economic Activity, 2007, 2, pp. 13-28.

\footnotetext{
${ }^{1}$ One way to gauge the severity of the recession is by comparing its duration with other recessions. Another way is to measure its depth, by looking at the decline in real GDP (or rise in the unemployment rate) relative to what would be expected during normal periods (expansion).

2 Survey of Professional Forecasters, February 13, 2009; minutes of the January 27-28, 2009, FOMC meeting.

${ }^{3}$ See www.nber.org/cycles/dec2008.html.

${ }^{4}$ The terminology is switched for the unemployment rate, since the unemployment rate rises during recession (a trough occurs before the business cycle peak).

${ }^{5}$ Excluding the largest and smallest changes from the 10 observations produces little change in the averages.

${ }^{6}$ Hall (2007) argues that this is a feature of recessions since 1990.

7 Indeed, the Blue Chip Consensus forecast released on March 10, 2009, increased (in absolute terms) the peak-to-trough decline in real GDP from 2.7 percent to 3.5 percent.

${ }^{8}$ In the February 17,2009 , SPF, the quarterly forecast horizon extends only to 2010:Q1.

${ }^{9}$ The NBER dated the peak in August 1929, but the unemployment rate is not available for that month. Instead, the table shows the percentage-point change from July 1929 to March 1933.
} 